\title{
The Empirical Analysis of the Quality Level of Tourism Industry Services in Toraja: Ke'te Kesu
}

\author{
Armin Darmawan*, Syamsul Bahri, Irfan Rahman \\ Department of Industrial Engineering, Faculty of Engineering, Universitas Hasanuddin, Makassar, Indonesia
}

\begin{abstract}
Indonesia has a number of tourism potentials to be built and developed sustainably. The destinations of local and overseas tourists have experienced an excellent growth trend in recent years, especially in North Toraja District, South Sulawesi. Therefore, the tourism industry is the government's main concern in recent years to increase its index because of its potential to boost the economic growth, especially for the local people and GDP. This study focused on the empirical analysis of the tourism industry service level that is viewed from the readiness and the support from available infrastructures. The method of this study was a survey distributed to respondents visiting the tourism industry using questionnaire based on SERVQUAL and IPA Diagram. By using SERVQUAL and Important Performance Analysis (IPA) method, we found eight service attributes which were divided into five SERVQUAL dimensions indicating that the service quality at Ke'te Kesu, North Toraja Regency, South Sulawesi needs to improve the aspects on Important Performance Analysis (IPA) diagram, including the service attribute: T5 (the availability of restaurants around the tourist location), T6 (the availability of street signs to tourist objects), R2 (the ease of finding tourist locations), R3 (the availability of public transportation to tourist location), RE4 (the immediate response from the officer/local citizen on the request or complain), RE5 (tourist Information Centre, contact person) is clear), A1 (Staffs are expert in serving tourists), and E5 (the concerns of tour operators and officers/residents to the needs of visitors). Sale in the floating market become a determinant of the sustainability of tourism activities in Lok Baintan Floating Market.
\end{abstract}

Keywords: Customer Satisfaction, IPA Diagram, Service Quality, Toraja, Tourism.

\section{INTRODUCTION}

Indonesia is a country with a million fascinating tourism along the equator, from Sabang to Merauke. This is a great potential to get more foreign exchange. In recent years, the government has seriously worked on this potential. It can be seen from their effort to develop existing tourist areas and make them as the priority tourism development programs by investing the development to create 10 New Bali which was estimated to spend \$20 billion [1]. The acceleration program for tourism development is an effort to reach the 2019 targets including the expectation to contribute to the GDP of $5.5 \%$ by collecting IDR 280 trillion of foreign exchange, creating 13 million jobs, and to bring the tourism competitiveness index to the top 30 by targeting 20 million foreign tourists and 275 million local tourists [2].

North Toraja is one of the favorite tourist destinations that become a priority visit for foreign and national tourists. The tourism office of Tana Toraja noted that the number of visits by both local and foreign tourist is 93,037 people (Table 1). This is the highest increase ever. This

\footnotetext{
${ }^{*}$ Correspondence address:

Armin Darmawan

Email : darmawanarmin@gmail.com

Address : Engineering Faculty, J.Poros Malino KM Kabupaten Gowa
}

increase becomes both challenge and opportunities for the region as well as the surrounding communities. One benefit for local and local communities is that it can certainly accelerate the economic growth. It is a way to introduce the widely-sustainable local culture and to contribute to the achievement of national foreign exchange earnings and GDP targets.

In addition to the opportunities described in the paragraph above, there are several challenges that need to be anticipated related to the increasing opportunities for this visit. The first is related to the level of service quality that supports tourism. This is important because it relates directly to tourists when accessing and interacting with these attractions. This has an effect on their expenditure level because the cost of several elements such as traveling, transportation, hotel, and other services is one of the main considerations in deciding tourist destinations [4]. The direct interaction to the good quality of facilities and services will build a positive impression and perception in consumers so that, indirectly, consumers will serve as a media campaign for other potential consumers.

The level of service quality has been proved to have a significant direct impact on the customer satisfaction level. Therefore, measurement and improvement of service quality is an important aspect of the 
management of rural tourism destinations [5]. This encourages the need for analysis in measuring the level of customer satisfaction to meet consumer needs, improve service quality, and create better service innovation [6].

Table 1. Number of Tourists at the Object of North Toraja Tour (April 2016 - March 2017)

\begin{tabular}{clr}
\hline No. & \multicolumn{1}{c}{ Tourism Object } & $\begin{array}{c}\text { Number of } \\
\text { visitors }\end{array}$ \\
\hline 1 & Ke'te Kesu & 93,037 \\
2 & Limbong & 2,376 \\
3 & Bori Kalimbuang & 4,494 \\
4 & Londa & 33,285 \\
5 & Galugu Dua & 167 \\
6 & To Barana' & 715 \\
7 & Palawa' & 1,218 \\
8 & Lo'ko Ma'ta & 279 \\
9 & Museum Landorundun & 275 \\
10 & Pala' Tokke & 114 \\
11 & Marante & 269 \\
12 & Tambolang & 954 \\
13 & Maruang & 3 \\
14 & Sarambu Sikore & 275 \\
15 & Lombok Parinding & 155 \\
16 & Ne' Gandeng & 1,700 \\
17 & Buntu Pune & 22 \\
18 & Pana' & 20 \\
19 & Pasar Bolu & 30 \\
20 & Singki' & 1,400 \\
21 & Lempe & 48 \\
22 & Tombi & 0 \\
23 & Tirotikua & 0 \\
\hline
\end{tabular}

Source: North Sulawesi Culture and Tourism Agency [3]

The method used in mapping the level of customer satisfaction and service quality level is SERVQUAL. Assessments using SERVQUAL factors were initiated by Parasuraman and others, which SERVQUAL scales were developed and used in the wider field of study $[7,8,9]$. SERVQUAL has been widely applied in service studies in various fields. It was designed to measure the quality of services based on the consumers' perspective. SERVQUAL consists of five dimensions of service quality including reliability, assurance, tangible, empathy, and responsiveness. SERVQUAL method is useful in identifying and analyzing the gap between what consumers expect and what they experience related to the quality of the service.

To map the output of SERVQUAL and to make it more specific, gap analysis is used to identify the gap between visitor expectations and their perceptions. Furthermore, to determine the service priority, the level of the performance and importance of a service using ImportancePerformance Analysis (IPA) diagram mapping. IPA which was introduced in 1977 by Martilla and James, is to identify which service or product attributes the company which is focusing on improving the customers' satisfaction [10].

The results of this analysis provide a portrait of what attributes are important and require a quality improvement based on consumer perceptions. This helps service providers in determining priority attributes that require immediate quality improvement. Then, the next step in the methodological development was the adoption of the IPA (Importance-Performance Analysis) approach as one of the methods used in determining the priority if there are alternative attributes that require quality improvement. The main purpose of this study was focused to provide a conceptual framework of service level for tourism industry through mapping the quality of services by empirical analysis.

\section{RESEARCH METHODS}

This study was conducted on one of the leading tourist attraction in South Sulawesi which is called Ke'te Kesu, a village in North Toraja. Ke'te Kesu is a cultural tourism object which got the highest number of visitor among the 23 tourist objects in Tana Toraja.

This study was conducted for four months which was from June to September 2017. Data collection was conducted through a survey by distributing questionnaires to 200 respondents who visited Ke'te Kesu Toraja. The survey used questionnaires that have been prepared in a structured and systematic way based on five dimensions of SERVQUAL.

Questionnaires were prepared based on the service attributes which were developed from five SERVQUAL dimensions. Those attributes are as follows in Table 2 . The assessment of respondents was based on Likert scale 1 - 5 to measure their expectations and perceptions. Qualitative data from the questionnaires were transformed into quantitative data which were processed using statistical analysis techniques namely the test validity and reliability.

\section{The Validity Test}

The measurement of research attribute validity is done by using the Pearson Product Moment correlation coefficient formula. The criterion is if $r$ calculate is greater than $r$ table, it means the data is valid. Conversely, if $r$ calculation is smaller than $r$ table, then data is invalid. Based on the $95 \%$ confidence level and alpha/margin error $=5$ percent with the number of preliminary survey samples of 20 respondents, 
$r$ table $=0.444$ with $n=20$. This means $d f=18(d f$ $=n-2)$ with a significance level of $0.05(95 \%)$.

Table 2. The Service Quality Dimension

\begin{tabular}{|c|c|}
\hline Code & Services \\
\hline T1 & The scenery is very interesting \\
\hline T2 & The tourist location is clean \\
\hline T3 & $\begin{array}{l}\text { Gift shop/ Souvenir Sale in tourism destination } \\
\text { is available }\end{array}$ \\
\hline T4 & $\begin{array}{l}\text { There is a festival or cultural event that is very } \\
\text { interesting to watch (Entertainment Facility: } \\
\text { Natural and Cultural Attraction) }\end{array}$ \\
\hline T5 & $\begin{array}{l}\text { There are restaurants or cafeteria available } \\
\text { around the tourist sites }\end{array}$ \\
\hline T6 & Directions to the attractions are available \\
\hline $\mathrm{T7}$ & $\begin{array}{l}\text { The public facilities around the tourist sites as } \\
\text { per the needs of tourists are available }\end{array}$ \\
\hline $\mathrm{R} 1$ & $\begin{array}{l}\text { The community around the tourist attraction is } \\
\text { very friendly }\end{array}$ \\
\hline $\mathrm{R} 2$ & $\begin{array}{l}\text { The tourist location is easy to find } \\
\text { (Accessibility) }\end{array}$ \\
\hline R3 & $\begin{array}{l}\text { Officers/locals are able to answer your } \\
\text { questions well and clearly }\end{array}$ \\
\hline R4 & $\begin{array}{l}\text { Clear tourist location information (available } \\
\text { website, tourist Information Centre, contact } \\
\text { person) are available }\end{array}$ \\
\hline R5 & $\begin{array}{l}\text { The price of admission offered at tourist sites } \\
\text { is in the accordance with the facilities offered } \\
\text { (Affordability) }\end{array}$ \\
\hline R6 & $\begin{array}{l}\text { Costs that should be spent during the tourists } \\
\text { are in the destination are affordable }\end{array}$ \\
\hline R7 & The clerk is friendly and polite in serving \\
\hline RE1 & $\begin{array}{l}\text { The communities around the tourist attraction } \\
\text { are very friendly }\end{array}$ \\
\hline RE2 & The tourist location is easy to find \\
\hline RE3 & Public transport to tourist sites is available \\
\hline RE4 & $\begin{array}{l}\text { Officers/locals are able to answer your } \\
\text { questions well and clearly }\end{array}$ \\
\hline RE5 & $\begin{array}{l}\text { Clear tourist location information (website, } \\
\text { tourist Information Centre, contact person) is } \\
\text { available }\end{array}$ \\
\hline A1 & Officers cater to tourists proficiently \\
\hline A2 & $\begin{array}{l}\text { Officers/locals are able to provide information } \\
\text { about your questions reliably }\end{array}$ \\
\hline A3 & $\begin{array}{l}\text { The safety and security of visitors are } \\
\text { guaranteed while in the attraction }\end{array}$ \\
\hline A4 & $\begin{array}{l}\text { Visitors feel comfortable, calm, and happy } \\
\text { during their stay at the tourist sites }\end{array}$ \\
\hline A5 & $\begin{array}{l}\text { The officer passes the information to the } \\
\text { visitor politely }\end{array}$ \\
\hline E1 & $\begin{array}{l}\text { Officers/residents easily build good } \\
\text { communication to visitors }\end{array}$ \\
\hline E2 & $\begin{array}{l}\text { Officers/locals give good attention to the } \\
\text { visitors }\end{array}$ \\
\hline E3 & The concierge/locals are friendly to visitors \\
\hline E4 & $\begin{array}{l}\text { Tourists and officers/residents are very } \\
\text { concerned about the needs of visitors }\end{array}$ \\
\hline E5 & $\begin{array}{l}\text { Officers/locals always greet and smile to the } \\
\text { visitors }\end{array}$ \\
\hline
\end{tabular}

To find out the correlation coefficient of validity, on each attribute of the research questionnaire, the calculation was processed by using SPSS Following is test results of the validity of the instrument (Table 3 ).

Table 3. Results of the Validity of the Instrument

\begin{tabular}{|c|c|c|c|}
\hline Code & $r$ calc. & $r$ table & Result \\
\hline $\mathrm{T} 1$ & 0.472 & 0.444 & Valid \\
\hline $\mathrm{T} 2$ & 0.707 & 0.444 & Valid \\
\hline T3 & 0.524 & 0.444 & Valid \\
\hline $\mathrm{T} 4$ & 0.447 & 0.444 & Valid \\
\hline T5 & 0.584 & 0.444 & Valid \\
\hline T6 & 0.737 & 0.444 & Valid \\
\hline $\mathrm{T7}$ & 0.564 & 0.444 & Valid \\
\hline $\mathrm{R} 1$ & 0.562 & 0.444 & Valid \\
\hline $\mathrm{R} 2$ & 0.660 & 0.444 & Valid \\
\hline R3 & 0.853 & 0.444 & Valid \\
\hline $\mathrm{R} 4$ & 0.449 & 0.444 & Valid \\
\hline R5 & 0.663 & 0.444 & Valid \\
\hline R6 & 0.481 & 0.444 & Valid \\
\hline R7 & 0.550 & 0.444 & Valid \\
\hline RE1 & 0.573 & 0.444 & Valid \\
\hline RE2 & 0.549 & 0.444 & Valid \\
\hline RE3 & 0.537 & 0.444 & Valid \\
\hline RE4 & 0.632 & 0.444 & Valid \\
\hline RE5 & 0.453 & 0.444 & Valid \\
\hline $\mathrm{A} 1$ & 0.966 & 0.444 & Valid \\
\hline $\mathrm{A} 2$ & 0.669 & 0.444 & Valid \\
\hline A3 & 0.988 & 0.444 & Valid \\
\hline A4 & 0.914 & 0.444 & Valid \\
\hline E1 & 0.762 & 0.444 & Valid \\
\hline E2 & 0.796 & 0.444 & Valid \\
\hline E3 & 0.625 & 0.444 & Valid \\
\hline E4 & 0.698 & 0.444 & Valid \\
\hline E5 & 0.612 & 0.444 & Valid \\
\hline E6 & 0.521 & 0.444 & Valid \\
\hline
\end{tabular}

\section{The Reliability Test}

The reliability of the measuring instrument was tested to determine whether the value of the instrument used to collect primary data from the research sample was reliable or unreliable. The reliable notion is that the measuring instruments which were used are reliable so that when they are used in different situations, the research questionnaire does not lead to very different perceptions. Testing that shows $r$ calculate $<r$ table means the data is not reliable, whereas if $r$ calculate $>r$ table, means the data is reliable.

Based on the selected level of confidence 95 percent and alpha/margin error $=5$ percent, with the number of preliminary survey sample was 20 respondents, $r$ table was 0.444 with $n=20$, which means that $\mathrm{df}=18(\mathrm{df}=\mathrm{n}-2$ ) with a significance level of 0.5 (95\%). The correlation coefficient of reliability obtained from the results of statistical calculations was compared with the table critical value product moment. The reliability testing using Cronbach's Alpha technique was assisted 
by the SPSS software for each SERVQUAL dimension. SPSS test results can be seen in table 4 below:

Table 4. The Result of Reliability Test

\begin{tabular}{lccl}
\hline \multicolumn{1}{c}{ Dimension } & r calc. & r table & Result \\
\hline \multicolumn{2}{l}{ Satisfaction/Perception } \\
Tangible & 0.731 & 0.444 & Reliable \\
Reliability & 0.727 & 0.444 & Reliable \\
Responsiveness & 0.689 & 0.444 & Reliable \\
Assurance & 0.840 & 0.444 & Reliable \\
Empathy & 0.765 & 0.444 & Reliable \\
\hline \multicolumn{2}{l}{ Expectation/Importance } & & \\
Tangible & 0.767 & 0.444 & Reliable \\
Reliability & 0.742 & 0.444 & Reliable \\
Responsiveness & 0.744 & 0.444 & Reliable \\
Assurance & 0.772 & 0.444 & Reliable \\
Empathy & 0.778 & 0.444 & Reliable \\
\hline
\end{tabular}

Based on the results of the instrument validity and reliability tests, data that obtained from the respondents who became the research sample was valid and reliable. Furthermore, the data was used as a reference for measuring the customer satisfaction.

Furthermore, the questionnaires were distributed to respondents (Ke'te Kesu visitors). The number of respondents was 200 including foreign tourists (who could speak any foreign languages that were understood by the researcher). Respondents were determined by using a random sampling technique and the number of respondents was decided based on population number of visitors to the hall. Of all respondents studied, the data obtained can be divided into some characteristics, i.e. gender, age, last education, occupation, tourist category, tourist related information, and the number of visits in the last 1 year.

\section{RESULT AND DISCUSSION Respondents}

This section of the study shows some of the results obtained from the survey in Ke'te Kesu, North Toraja (Fig. 1). A brief description of the characteristics of respondents can be seen in Table 5. The characteristics consist of gender, age, last education, occupation, and types of tourists.

Based on the five characteristics, there are three specific categories that dominate why visitors decide to Ke'te Kesu. The three dominant characteristics were: people who were categorized as students from 15-30 years old and were in the local tourist group. This provided opportunities for service providers to explore these characteristics in order to improve the quality of tourist visits.

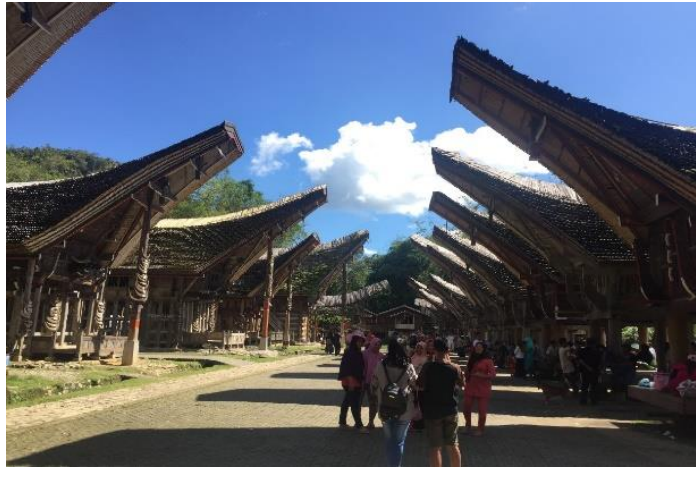

Figure 1. One of the Tourist Objects at Ke'te Kesu North Toraja (Personal Documentation, 2017)

Table 5. Characteristics of Respondents

\begin{tabular}{|c|c|c|}
\hline $\begin{array}{c}\text { Social } \\
\text { Attributes } \\
\text { and } \\
\text { Demography }\end{array}$ & Sub Attributes & Percentage (\%) \\
\hline \multirow{2}{*}{ Gender } & Male & 46 \\
\hline & Female & 54 \\
\hline \multirow{5}{*}{ Age } & $<20$ years & 13 \\
\hline & $21-30$ years & 62 \\
\hline & $31-40$ years & 20 \\
\hline & $41-50$ years & 5 \\
\hline & $>50$ years & 0 \\
\hline \multirow{5}{*}{ Education } & Elementary School & 1 \\
\hline & Junior High School & 8 \\
\hline & Senior High School & 18 \\
\hline & Higher Education & 61 \\
\hline & Other & 12 \\
\hline \multirow{5}{*}{ Occupation } & Student & 58 \\
\hline & $\begin{array}{l}\text { Civil Servants/ } \\
\text { Army/Police }\end{array}$ & 9 \\
\hline & Entrepreneurship & 15 \\
\hline & Private Sector & 17 \\
\hline & Other & 1 \\
\hline Tourist & Local & 96 \\
\hline Category & International & 4 \\
\hline
\end{tabular}

\section{Gap Analysis}

In improving service quality, the following are the results of service level identification from the gap analysis for each attribute developed from the five SERVQUAL dimensions. The gap score for each item attribute was calculated by subtracting the expectation score from the perception score. The results in Table 2 show that the differences between perceptions and expectations for all 29 attributes and five dimensions are generally ranged in negative mean (Tangible: -0.48 , Reliability: -0.49, Responsiveness: -0.68 , Assurance: -0.52, Empathy: -0.49). Indicating that there are a lot of service improvements efforts need to be fulfilled to enhance the service quality. 
Tourism Industry Services in Toraja:

Ke'te Kesu (Darmawan et al)

Table 6. Gap Analysis SERVQUAL

\begin{tabular}{|c|c|c|c|c|}
\hline Dimension & Code & $\begin{array}{l}\text { Satisfaction } \\
\text { / Perception } \\
\end{array}$ & $\begin{array}{l}\text { Importance/ } \\
\text { Expectation }\end{array}$ & Gap \\
\hline \multirow[t]{7}{*}{ Tangible } & $\mathrm{T} 1$ & 4.35 & 4.48 & -0.13 \\
\hline & $\mathrm{T} 2$ & 4.00 & 4.22 & -0.22 \\
\hline & T3 & 4.33 & 3.96 & 0.37 \\
\hline & $\mathrm{T} 4$ & 4.23 & 3.91 & 0.32 \\
\hline & T5 & 2.6 & 4.23 & -1.63 \\
\hline & T6 & 2.63 & 4.34 & -1.71 \\
\hline & T7 & 3.89 & 4.28 & -0.39 \\
\hline \multirow[t]{7}{*}{ Reliability } & R1 & 4.08 & 4.17 & -0.09 \\
\hline & $\mathrm{R} 2$ & 2.77 & 4.29 & -1.52 \\
\hline & R3 & 2.67 & 4.4 & -1.73 \\
\hline & R4 & 4.15 & 4.09 & 0.06 \\
\hline & R5 & 4.04 & 4.21 & -0.17 \\
\hline & R6 & 4.18 & 4.1 & 0.08 \\
\hline & R7 & 4.12 & 4.2 & -0.08 \\
\hline \multirow[t]{5}{*}{ Responsiveness } & RE1 & 3.89 & 4.21 & -0.32 \\
\hline & RE2 & 3.86 & 4.26 & -0.4 \\
\hline & RE3 & 3.61 & 4.18 & -0.57 \\
\hline & RE4 & 2.83 & 4.27 & -1.44 \\
\hline & RE5 & 3.62 & 4.29 & -0.67 \\
\hline \multirow[t]{4}{*}{ Assurance } & $\mathrm{A} 1$ & 2.93 & 4.33 & -1.4 \\
\hline & $\mathrm{A} 2$ & 4.03 & 3.89 & 0.14 \\
\hline & A3 & 4.01 & 4.4 & -0.39 \\
\hline & A4 & 4.07 & 4.51 & -0.44 \\
\hline \multirow[t]{6}{*}{ Empathy } & E1 & 4.08 & 4.27 & -0.19 \\
\hline & E2 & 3.99 & 4.28 & -0.29 \\
\hline & E3 & 2.62 & 4.05 & -1.43 \\
\hline & E4 & 4.14 & 4.29 & -0.15 \\
\hline & E5 & 3.67 & 4.27 & -0.6 \\
\hline & E6 & 4.02 & 4.3 & -0.28 \\
\hline
\end{tabular}

The results of gap analysis generally indicated that the level of service quality that the visitors expected were still higher than the one that they perceived during the visit. Among the 29 service attributes, 25 service attributes were perceived to be low by visitors, while 4 other service attributes were perceived positively and appealing to visitors. On the tangible dimension side, it was found that the tour was enlivened by festivals and local cultural performances and completed with a gift shop to buy unique souvenirs that characterize Ke'te Kesu.

Information on tourism on the reliability dimensions, the friendly welcome and acceptance by local residents showed a positive state. The perception of visitors associated with the costs incurred during the visit is quite affordable. This finding is slightly different from previous study, according to visitors that the cost they spent in tourism destination was quite high [11]. For that, the research recommended to tourism destination to consider reasonable prices.

\section{Importance-Performance Analysis (IPA)}

The IPA diagram is divided into four quadrants where the first and second quadrants reflect the level of attributes that are very important. In both diagrams it is found that there are 17 attributes that are considered important by service users. These 17 attributes are distributed in two parts where the left side shows a low level of performance and the right part shows a satisfactory level of performance, eight attributes to the left side (northwest corner side) and nine attributes to the right side.

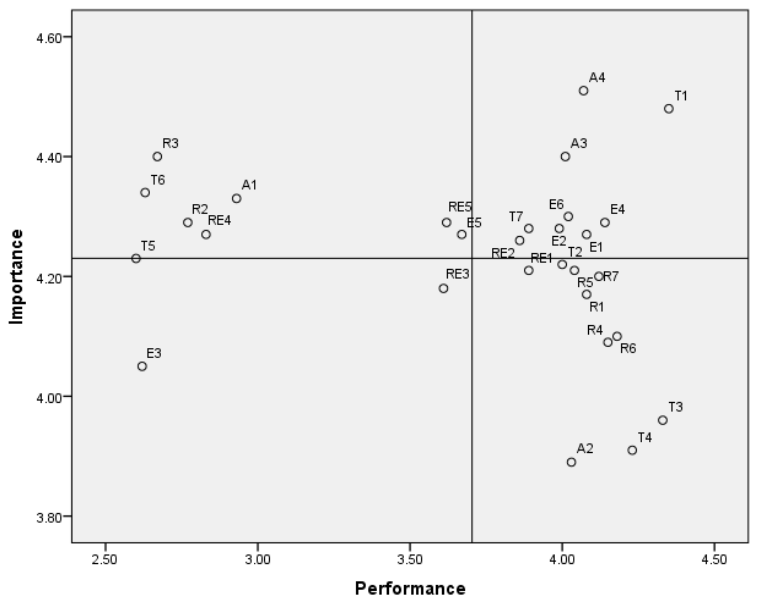

Figure 2. Diagram of Importance-Performance Analysis

Whereas third and fourth quadrants reflect the level of attributes that are not important for service users. There are 12 attributes described in these two diagrams, two attributes in left side and 10 attributes in right side. It means that these attributes dominantly in good performance even though these attributes were not as important as those in top sides.

Furthermore, from the gap analysis, priority determination to improve the quality of service was done through mapping ImportancePerformance Analysis (IPA) Diagram, particularly in upper-left side. From the results of data processing through the diagram of IPA (Important Performance Analysis), there are eight service attributes that became the main priority to make service improvements (appears in upper-left). The service attributes that the service improvement would handle were the ones in quadrant $A$ of each tangible dimension (physical proof), reliability, responsiveness, assurance, empathy. For more details, please see the Table 7.

Regarding the findings, several attributes can be connected are related to the environment of the tourism destinations, such as the availability of places for food and beverages, directions to location, public transportation, and information center. These finding differ to previous research mainly related to that tourist destination is 
environmentally friendly, tourist destination offered food and beverage that are clean and hygienic [11]. In another research, several findings from the study conducted by Tendean showed that the availability of dining area and transport are some of problems that need attention to be improved [12].

Table 7. The Service Attributes that Need Improvement

\begin{tabular}{|c|c|c|}
\hline No & Code & Service Attributes \\
\hline 1 & T5 & $\begin{array}{l}\text { There are restaurants around the tourist } \\
\text { sites }\end{array}$ \\
\hline 2 & T6 & Directions to the attractions are available \\
\hline 3 & $\mathrm{R} 2$ & The tourist location is easy to find \\
\hline 4 & R3 & $\begin{array}{l}\text { Public transport to tourist sites is } \\
\text { available }\end{array}$ \\
\hline 5 & RE4 & $\begin{array}{l}\text { Officers/local residents immediately } \\
\text { respond to requests or complaints }\end{array}$ \\
\hline 6 & RE5 & $\begin{array}{l}\text { Tourist location information (website, } \\
\text { tourist information center, contact } \\
\text { person) is clear }\end{array}$ \\
\hline 7 & A1 & Staffs are expert in serving tourists \\
\hline 8 & E5 & $\begin{array}{l}\text { Tourists and officers/residents are very } \\
\text { concerned about the visitors' needs }\end{array}$ \\
\hline
\end{tabular}

\section{The Improvement Plan of Services}

To get customer loyalty, special study is needed to conduct on the participatory of all stakeholders of tourism objects and the North Toraja District Culture and Tourism Office. This loyalty will have a positive effect on the tourism industry including Ke'te Kesu and other attractions to increase visitor loyalty and number of visits. It is important to realize that the visitor's perception and expectation plays an important role in the process of assessing the overall level of service quality. At the beginning of the visit, visitors will have a certain level of expectation or confidence in a certain standard of service. The expectation is then compared to the actual service that they perceived or experienced [13]. In other case, flight services, practitioners should focus on delivering superior service quality and provide high value of service in order to improve the customer satisfaction. The study shows that service quality and perceived value contribute directly to customer satisfaction [9].

The improvement plan on the customer satisfaction in this research would be taken as the input to the manager to enhance service improvement based on improvement priority. The input included specific steps from customer/ visitor satisfaction issues faced and actions that could be taken by the manager.

Some strategies can be developed based on the eight attributes that are of concern for immediate improvement in quality. The strategy can be grouped into three parts, namely physical and transportation facility development (T5, T6, R2, R3), development of integrated information systems (R2 and RE5), and human resource development (RE4, A1, E5). By implementing these strategies, it is expected that it can help to develop the quality of services for tourists while visiting tourist spots in Tana Toraja.

\section{Development of Physical and Transportation Facility}

Development of physical facilities can be developed by upgrading modern facilities without eliminating the local characteristics of a tourist area. Provides an attractive restaurant with local characteristics which also serves local specialties and food. The provision of this restaurant also considers the character of tourists who are generally young and educated (Table 5). Access to easy locations supported by transportation facilities is the second thing that needs to be developed to improve service quality. In addition, the need to be developed is a location sign board and information board related to the history and characteristics of a tourist spot that can be presented in three languages (Local Language, Indonesian Language, and English).

\section{Development of Integrated Information Systems}

An integrated information system is a priority for development. The ease of access to information will make the Toraja tourist area more attractive to visit. Some things that need to be developed in this information system are interesting tourist spot services, cultural performance information and schedules, types and access to transportation, maps that integrate a lot of general information such as location distance, tourist spots, restaurants, places of worship, and hotels.

\section{Development of Human Resources}

To improve services, it is necessary to improve service skills for service providers. This can be improved by developing a standard of service for tour guides and others that focus on meeting customer (tourist) needs and satisfaction.

Listed below is an overview of programs that could be offered to services industries in increasing the customer or visitors' satisfaction and loyalty (Fig. 3). The management of tourist objects also needs to conduct an upgrading to deepen the ability of its officers in serving visitors 
related to their needs during they are in the tourist areas.

Furthermore, as a leading tourist area, local governments must encourage this potential to be developed further. One strategy that can be applied is to benchmark the developed tourist areas. In addition, the regional government needs to maximize by optimizing local potentials that have not yet been explored.

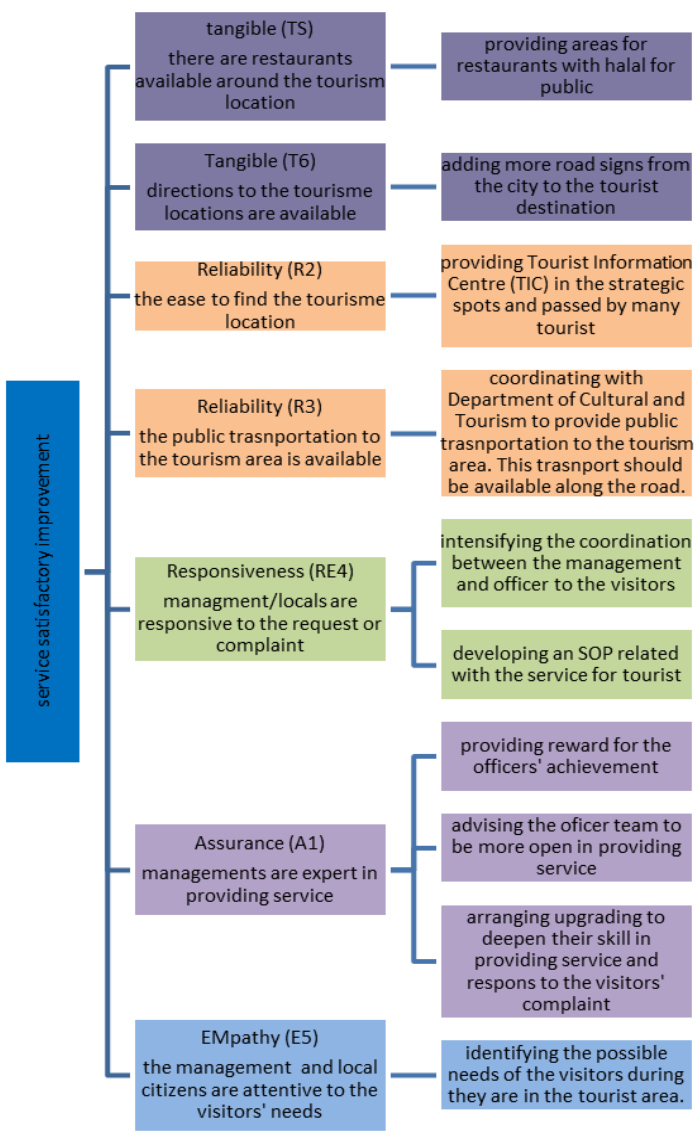

Figure 3. The List of Actions for Service Improvements

This study has limitations of the results. First; the results are based on one tourism services, so it needs to extend in other tourism services in the country in enrichment of findings. Second; most respondents from this study were local tourist, future research might include more international visitors to get more findings. Also, perceptions of service quality in the tourism sector from other stakeholders' perspectives such as staff, guide, government, etc. should be considered. Finally, a wide study needs to extend the result of investigation.

\section{CONCLUSION}

Based on the result of SERVQUAL Score data calculation on each dimension, generally the visitor or the customer has not been satisfied with the performance of the tourism management based on the service that they provided with the tangible dimension of $88.57 \%$, reliability dimension of $88.76 \%$, responsiveness dimension of $83.96 \%$, assurance dimension of $87.85 \%$, and the empathy dimension of $88.44 \%$. Considering 29 service attributes with five SERVQUAL dimensions, the positive gaps which were obtained including five service attributes ranging from 0.06 to 0.37 and 24 service attributes with negative gap values ranging from -0.08 to -1.73 .

The result of IPA (Important Performance Analysis) analysis showed that among 29 service attributes, there were eight items that became the main priority of the improvement that were, T5 (there are restaurants around tourist location) and T6 (directions to the tourism object are available ) in the tangible dimensions, R2 (the tourist sites are easy to find) and R3 (public transport to tourist sites are available) from reliability dimensions, service attributes RE4 (officers / local residents respond immediately to requests or complaints) from responsiveness dimension, A1 (officers are expert in serving tourists) from assurance dimension, and E5 (tourism object manager and officer/citizen are very attentive to visitor requirement) from empathy dimension.

There are three strategies that can be developed to enhance the quality of services. First, upgrade physical facilities and transportation. Second, build integrated information systems. Third, develop the capabilities and competencies of human resources.

\section{REFERENCES}

[1] Syarizka, D., I. Agustine and S. Munowaroh. 2018. Pengembangan destinasi wisata priotitas. Bisnis Indonesia. PT Jurnalindo Aksara Grafika. Jakarta.

[2] Thaib, H. S. 2018. Menciptakan lokomotif wisata (perspektif). Bisnis Indonesia. PT Jurnalndo Aksara Grafika. Jakarta.

[3] North Toraja Regency. 2017. Tourist object in North Toraja. North Sulawesi Culture and Tourism Agency.

[4] Bimonte, S., S. Ferrini and A. G. Grilli. 2015. Transport infrastructure, environmetal impact, and tourists' welfare. Journal of Environmental and Management, 1-20.

[5] Rajaratnam, S. D., U. T. Munikrishnan, S. P. Sharif and V. Nair. 2014. Service quality and 
previous experience as a moderator in determining tourists' satisfaction with rural tourism destination in Malaysia: A Partial least square approach. Procedia Social and Behavioral Sciences, 203-201.

[6] Titu, M. A., A. S. Raulea and S. Titu. 2016. Measuring service quality in tourism industry. Procedia Social and Behavior, 294 - 301.

[7] Parasuraman, A., L. Berry and V. Zeithaml, 1991. Revinement and reassesment of the SERVQUAL scale. Journal of Retailing 67 (4), 420-450.

[8] Darmawan, A., M. Mulyadi and F. Fauziah. 2017. Evaluasi kualitas layanan terhadap operator telekomunikasi: tinjauan perspektif pelanggan. Jurnal Optimasi Sistem Industri 16(2), 106-111.

[9] Hapshari, R., M. Clemes and D. Dean, 2016. The mediating role of perceived value on the relationship between service quality and customer satisfaction: evidence from Indonesian airline passengers. Procedia Economics and Finance, 388-395.

[10] Wang, R. and M. L. Tseng. 2011. Evaluation of international student satisfaction using Fuzzy Importance-Performance Analysis. Procedia - Social and Behavioral Sciences, 438-446.

[11] Choovanichchannon, C. 2015. Satisfaction in Thai standard of tourism quality. Procedia Social and Behavioral Sciences, 2110-2114.

[12] Tendean, C. 2017. Analysis of tourist satisfaction to tourist attraction quality in Kediri Regency, East Java. Journal of Indonesian Tourism and Development Studies 5(2), 91-100.

[13] Vajcnerova, I., P. Ziaran, K. Ryglova and I. Andrasko. 2014. Quality management of the tourist destinantion in the context of visitors' satisfaction. Procedia Economics and Finance, 718-724. 